\title{
The Implementation of Student Discipline Through School Rules
}

Isna Sofia Dewi ${ }^{1^{*}}$, Nana Hendracipta ${ }^{2}$, Ahmad Syachruro $i^{3}$

1,2,3 Prodi Pendidikan Guru Sekolah Dasar, Universitas Sultan Ageng Tirtayasa, Banten, Indonesia

*Email: isna.sofia98@gmail.com¹, nanahendracipta@untirta.ac.id², ahmadsyachruroji@untirta.ac.id³

\begin{abstract}
Banyaknya masalah karakter yang dialami oleh Indonesia menguatkan urgensi penanaman dan penerapan pendidikan karakter. Salah satu penanaman karakter yang diperlukan ialah karakter disiplin. Penelitian ini bertujuan untuk menganalisis dampak penanaman karakter disiplin siswa melalui tata tertib sekolah. Penelitian ini menggunakan metode kualitatif deskriptif dengan teknik pengumpulan data yang digunakan dalam peneltitian ini yaitu menggunakan observasi, wawancara, dan dokumentasi. Sumber data dalam penelitian ini berasal dari kepala sekolah, guru pengajar kelas 5, dan siswa. Hasil penelitian menunjukkan bahwa melalui tata tertib sekolah, penanaman karakter disiplin dilakukan dengan tahap awal yakni penyusunan perencanaan dan pengembangan karakter disiplin, sarana dan prasarana yang disediakan juga dapat menunjang penanaman karakter disiplin siswa. Selain itu, guru dan kepala sekolah juga selalu memberikan contoh nyata perilaku karakter disiplin. Pada proses penanaman karakter disiplin tentu terdapat hambatan dan kendala tetapi kepala sekolah dan guru bersama-sama saling berkomunikasi dan juga bekerja sama dengan wali murid siswa dalam mengatasi hambatan yang terjadi. Implikasi penelitian ini yaitu dapat memberikan pemahaman mengenai analisis dampak penanaman karakter disiplin siswa melalui tata tertib sekolah, sehingga dapat memberikan kontribusi dalam pencapaian prestasi siswa dan sekolah.
\end{abstract}

Kata Kunci: Pendidikan Karakter, Disiplin, Tata Tertib

\begin{abstract}
The number of character problems experienced by Indonesia strengthens the urgency of planting and implementing character education. One of the necessary character plantings is the character of discipline. This study analyzes the impact of teaching student discipline characters through school rules. This study uses descriptive qualitative methods with data collection techniques used in this research using observation, interviews, and documentation. Sources of data in this study came from the principal, 5th-grade teaching teachers, and students. The study results indicate that the cultivation of disciplinary character is carried out through school rules in the early stages, namely the preparation of planning and development of disciplinary characters. Facilities and infrastructure provided can also support the inculcation of students' disciplined characters. In addition, teachers and principals also always provide concrete examples of the behavior of disciplined characters. In teaching the character of discipline, of course, there are obstacles and obstacles. However, the principal and teachers communicate and work together with the students' parents to overcome the obstacles. This research implies that it can explain the impact of planting student discipline characters through school rules to contribute to student and school achievement.
\end{abstract}

Keywords: Character Education, Discipline, Rules

\section{INTRODUCTION}

School is an alternative to implement character education. Schools also help teach good habits and develop good behavior or character. This situation will help parents who have not been

\footnotetext{
${ }^{*}$ Corresponding author.

Received December 20, 2020; Accepted July 14, 2021; Available online October 25, 2021

This is an open access article under the CC BY-SA license. Copyright @ 2021 by Author. Published by Universitas

Pendidikan Ganesha.
} 
able to apply character education to their children at home. Discipline needs to be applied in schools through school rules applied by all school communities and in the future. This character can be embedded in each individual. School rules are a unit that cannot be separated from one another as rules that apply in schools to run effectively and efficiently. (Bell, 2020; Cho et al., 2020).

Rules in the school need to be applied in the teaching and learning process. They can help learn activities, create a sense of pleasure, and improve social relations. Discipline and responsibility are very important and needed by every student to develop attitudes, behaviors, and rules of life that will lead a student to succeed in learning (Akbar, 2010; Pierce et al., 2021). The implementation of the discipline itself must go through rules because discipline is an action that shows orderly behavior and obeys various rules and regulations. Therefore, the rules in an institution must be mutually agreed upon (Cattelino et al., 2019; Dontcheva-Navratilova, 2021; Neshat et al., 2011).

Based on the observations, it is known that all school members must follow the rules at SD Negeri Ciruas 4, and it has been going well. If anyone commits a violation, the appropriate sanctions will be imposed. For example, if someone is late, the student must face the picket teacher to get punished. The punishments are cleaning the schoolyard or running around the field. Every Thursday, the school holds a Pagi Kamis Manis Membaca (Pak Kumis) in front of their respective classes attended by the principal, teachers, and students. On Friday, the school held a Kultum program which all students filled. On Saturdays, they have a gymnastics program with the principal, teachers, and students, and on Saturday afternoons, students are required to participate in Scouting activities. However, during the pandemic, all students did distance learning by the teacher. However, after the PSBB, the $5 \mathrm{~A}$ teacher proposed to form 4 study groups that were still in the same environment. The teacher works with the student's parents to provide group learning. Many teachers at SD Negeri Ciruas 4 want to hold study groups, but limited space is a barrier. All of these activities are carried out to implement the disciplined character of students.

Discipline character is an important character given to elementary school students because it will bring up other good characters. Discipline provides a major contribution to developing children's character and behavior. Discipline is defined as a person's self-control against various applicable rules (Goddard et al., 2021; Thomas et al., 2020). There are several indicators of student discipline: coming to school on time, ending learning activities and going home according to schedule, wearing complete school uniforms, maintaining cleanliness and neatness of clothes, including notification letters to school if students are unable to attend, following the learning process well, following and carrying out extracurricular activities, doing assignments given by the teacher, carrying out class picket assignments according to the specified schedule, and managing study times. One of the biases that can be done to implement the character of discipline can be done through school rules. School rules are good rules or regulations from consistent implementation of existing regulations. The rules of order in school rules' regularity include obligations, obligations, and prohibitions. School rules are arranged operationally to regulate students' behavior and attitudes, teachers, and administrative staff at the school concerned (Fabbri et al., 2021; Oosterbeek et al., 2021; Stark \& Bettini, 2021). The implementation of school discipline is to improve student learning discipline will run well if teachers, school officials, and students have mutually supported the school discipline itself. The lack of support from students and school stakeholders will result in less meaningful school rules being implemented.

Previous research findings indicate that cultivating disciplined character can be done through school rules (Apriani \& Wangid, 2015; Permatasari et al., 2021). Developing student discipline is necessary for the success of character education in schools and can be done through school rules (Anzalena et al., 2019). Compliance with school rules positively affects student learning discipline (Sari \& Irianto, 2020). This study analyzes the impact of developing student discipline characters through school rules.

\section{METHOD}

This study uses a descriptive method in a qualitative approach (Sugiyono, 2016). Qualitative descriptive research describes existing phenomena, focusing more on the characteristics, quality, and interrelationships between activities. In addition, descriptive research does not provide treatment, manipulation, or modification of the variables studied but described a condition as it is. The only treatment was the research conducted through observation, 
interviews, and documentation. This research was conducted at SD Negeri Ciruas 4, Kabupaten Serang-Banten, involving the principal and teachers as informants.

\section{RESULT AND DISCUSSION}

\section{Result}

Based on observations, it is known that students arrive on time. It can be seen from group study starting at 08.00 WITA, and each group must be ready at that hour. Students are also neatly dressed. Students do not speak rudely to their friends. Students do good to their friends. Students participate in group study with enthusiasm. Students have done their homework, only a few students do not use their masks when carrying them, students clean the place, and students rarely pay attention to the teacher because the number of students is small. The teacher can control students well. After finishing discussing the material, students are asked to ask questions. Students help explain the material to friends who do not understand. Not always the whole group is enthusiastic, sometimes only one or only two people answer, and students discuss with friends about learning.

Based on the interview results, it is known that the character of time discipline, work discipline, and learning discipline are very important as provisions for students in living life. Building discipline is carried out by applying discipline and exemplifying good attitudes such as arriving on time, participating in activities involving all school members, and coordinating with other teachers because the teacher often communicates directly with students, especially during a pandemic. In addition, the learning activities carried out are also accompanied by character learning in the first way, seen from the theme, and see what the learning activities. Usually, in thematic books, there are activities that students must do. The 2013 curriculum also has character education, such as spiritual and social. If they go to the core of learning, the first thing is that they have to look at the theme or sub-theme when they start learning so that it will later be linked to students' daily activities. In addition, it is also known that the form of activity in the application of discipline to instill the value of discipline is a routine flag ceremony activity by requiring all school members to follow it and wear complete clothes and attributes. Character education is implemented through habituation and extracurricular activities such as reading Asmaul Husna and short letters before starting learning. In addition, other activities are getting students to read every Thursday before starting learning. There is also a cult that familiarizes students to be confident in appearing in front because the cult itself is the student who delivers. Joint gymnastics activities are carried out together, and there is a clean Saturday. After completing the learning, the students clean the classroom and the classroom environment. For extracurricular activities, schools require students to participate in Scouts. Some are not required, such as drumband, karate, and silat.

The way to instill a disciplined character when there is no face-to-face learning is to remind students that they still have to study and complete their assignments, but if they are studying in groups by making rules. Due to the pandemic, we must always follow health protocols to remind us to wear masks and keep our distance. There are also obstacles in shaping children's character, including children who are too indifferent and do not care. It usually has to be extra patient to tell him. The way to overcome these obstacles is to continue to be patient in providing understanding and setting an example for good things. The way to shape the character of students' discipline with the infrastructure provided is to train students to be consistent and maintain commitment in their duties. Before this pandemic, students had a picket schedule, so they also had to be disciplined in doing their assignments and storing their cleaning tools. Students were also asked to take care of the plants in front of the class. All of that can indirectly shape the character of students who must be responsible for the cleanliness of the classroom. Ways to build communication with students include setting a good example, always following the activities held, coming on time, and greeting each other when they meet. Every Thursday, when reading with the principal, he often reads with the students to motivate them to enjoy reading because students see the teachers and principals reading. During the gymnastics, the principal and all the teachers participated, not just from the front of the office.

\section{Discussion}

The development of character education is one solution to having good character. Character development is a process of developing values for students always to carry out their duties and obligations based on a disciplined attitude and full of responsibility (Dewi et al., 2019; Handayani, 2016; Murniyetti et al., 2016). Character development is very important for students, 
especially time discipline, worship discipline, and learning discipline, who will later get used to discipline. In addition to the most important discipline, moral development will also make students disciplined, responsible, caring for their friends, and honest.

The teacher carries out the development of disciplined character in students by providing examples through teacher behavior. Teachers carry out all plans that affect their students' character development, understanding values as a whole. The teacher can also be a friend to the students, so the teacher must have a close relationship with them so that students do not hesitate to tell stories when they have problems. Teachers must also be able to see whenever their students have problems and provide solutions to problems faced by their students. Teachers are not merely as teachers but also as educators and at the same time as mentors who provide direction and guide students in learning. In addition, in developing student character, schools make rules that students and activities for students can obey. Of course, this is one of the activity factors that can make students grow their character, especially the character of discipline by obeying the rules and participating in extracurricular activities that must be followed.

Discipline character development is very important for schools and teachers using infrastructure suggestions that can indirectly develop students' character (Fabbri et al., 2021; Tanto et al., 2019; Triki, 2021). In addition to student discipline, it is also the responsibility of the facilities and infrastructure for students to be more diligent in cleaning and maintaining them. In implementing disciplinary character development activities, there are obstacles. However, to overcome obstacles in inculcating student discipline characters, it is necessary to communicate between school principals, teachers, and parents of students. Teachers must often communicate with parents, especially now that the whole world is experiencing a pandemic and the learning process through online learning. Communication is a social competence possessed by the teacher in which the teacher socializes with the guardians of students. Social competence is the ability of teachers to communicate and interact effectively with students, fellow educators, education staff, parents of students, and the surrounding community (Afriadi \& Dahlia, 2020; Hazadiyah et al., 2018; Syukur, 2015). Teachers must be able to do things including 1) communicating orally and in writing, 2) using communication and information technology functionally, 3) interacting effectively with students, fellow educators, education staff, parents. 4) show a mature and exemplary personality to realize these aspects in every action and behavior.

Previous research findings indicate that the development of disciplined character can be done through school rules (Apriani \& Wangid, 2015; Permatasari et al., 2021). Developing student discipline is necessary for the success of character education in schools and can be done through school rules (Anzalena et al., 2019). Compliance with school rules positively affects student learning discipline (Sari \& Irianto, 2020). This research implies that it can explain the analysis of the impact of planting student discipline characters through school rules to contribute to student and school achievement.

\section{CONCLUSION}

Discipline character development is very important for schools and teachers using infrastructure suggestions to develop student character. In addition to student discipline, it is also the responsibility of the facilities and infrastructure for students to be more diligent in cleaning and maintaining them. In implementing disciplinary character development activities, there are obstacles. It is necessary to communicate between school principals, teachers, and parents of students to overcome obstacles in developing student discipline character. The impact on the development of student discipline character can be seen that students become role models. They follow what their teachers have exemplified, such as participating in activities at school. Students are also responsible for carrying out the assigned tasks or carrying out predetermined rules such as carrying out pickets, not littering, and being on time to collect assignments.

\section{REFERENCES}

Afriadi, B., \& Dahlia, D. (2020). Suvervisi Guru Menggunakan Alat Penilaian Kompetensi Guru (Apkg) Pada Penilaian Komponen Kepribadian Dan Sosial Guru Di Sdn Jurumudi 5 Kota Tangerang. Jurnal Evaluasi Pendidikan, 11(2), 67-72. https://doi.org/10.21009/10.21009/jep.0124.

Akbar, S. (2010). Model Pembelajaran Nilai dan Karakter Berbasis Nilai-Nilai Kehidupan di Sekolah Dasar. Jurnal IImu Pendidikan, 17(1), 46-54. https://doi.org/ 10.17977/jip.v17i1.2619. 
Anzalena, R., Yusuf, S., \& Lukman, L. (2019). Faktor Penyebab Indisipliner Siswa dalam Mematuhi Tata Tertib di Sekolah Dasar. Jurnal PGSD, 12(2), 123-132. https://doi.org/10.33369/pgsd.12.2.123-132.

Apriani, A.-N., \& Wangid, M. N. (2015). Pengaruh SSP Tematik-Integratif Terhadap Karakter Disiplin dan Tanggung Jawab Siswa Kelas III SD. Jurnal Prima Edukasia, 3(1), 12-25. https://doi.org/10.21831/jpe.v3i1.406.

Bell, C. (2020). "Maybe if they let us tell the story I wouldn't have gotten suspended": Understanding Black students' and parents' perceptions of school discipline. Children and Youth Services Review, 110(October 2019), 104757. https://doi.org/10.1016/j.childyouth.2020.104757.

Cattelino, E., Morelli, M., Baiocco, R., \& Chirumbolo, A. (2019). From external regulation to school achievement: The mediation of self-efficacy at school. Journal of Applied Developmental Psychology, 60(September), 127-133. https://doi.org/10.1016/j.appdev.2018.09.007.

Cho, V., Mansfield, K. C., \& Claughton, J. (2020). The past and future technology in classroom management and school discipline: A systematic review. Teaching and Teacher Education, 90. https://doi.org/10.1016/j.tate.2020.103037.

Dewi, A. K. T., Degeng, I. N. S., \& Hadi, S. (2019). Implementasi Pendidikan Nilai Karakter di Sekolah Dasar Melalui Budaya Sekolah. Jurnal Pendidikan: Teori, Penelitian, Dan Pengembangan, 4(2), 247-255. https://doi.org/10.17977/jptpp.v4i2.12011.

Dontcheva-Navratilova, O. (2021). Engaging with the reader in research articles in English: Variation across disciplines and linguacultural backgrounds. English for Specific Purposes, 63, 18-32. https://doi.org/10.1016/j.esp.2021.02.003.

Fabbri, C., Bhatia, A., Petzold, M., Jugder, M., Guedes, A., Cappa, C., \& Devries, K. (2021). Modelling the effect of the COVID-19 pandemic on violent discipline against children. Child Abuse and Neglect, 116(December), 104897. https://doi.org/10.1016/j.chiabu.2020.104897.

Goddard, E., Grant, R., Tatman, L., Baltzly, D., de la Barra, B. L., \& Black, R. (2021). Women in Philosophy, Engineering \& Theology: Gendered disciplines and projects of critical reimagination. Women's Studies International Forum, 86(May). https://doi.org/10.1016/j.wsif.2021.102479.

Handayani, T. K. (2016). Nilai-Nilai Karakter Dalam Tindak Tutur Ilokusi Dalam Buku Wir Besuchen Eine Moschee. Litera, 15(2), 305-318. https://doi.org/10.21831/ltr.v15i2.11831.

Hazadiyah, D., Kardinah, N., \& Sunardi, I. (2018). Hubungan Antara Kompetensi Sosial Dan Kepercayaan Diri Pada Siswa. Psympathic: Jurnal IImiah Psikologi, 5(2), 667-676. https://doi.org/10.15575/psy.v5i2.2160.

Murniyetti, M., Engkizar, E., \& Anwar, F. (2016). Pola Pelaksanaan Pendidikan Karakter Terhadap Siswa Sekolah Dasar. Jurnal Pendidikan Karakter, 6(2), 156-166. https://doi.org/10.21831/jpk.v6i2.12045.

Neshat, N., Mahloojifl, H., \& Kazemi, A. (2011). An enhanced neural network model for predictive control of granule quality characteristics. Scientia Iranica, 18(3 E), 722-730. https://doi.org/10.1016/j.scient.2011.05.019.

Oosterbeek, H., ter Meulen, S., \& van der Klaauw, B. (2021). Long-term effects of school-startingage rules. Economics of Education Review, 84, 102144. https://doi.org/10.1016/j.econedurev.2021.102144.

Permatasari, N. A., Setiawan, D., \& Kironoratri, L. (2021). Model Penanaman Karakter Disiplin Siswa Sekolah Dasar pada Masa Pembelajaran Daring. Edukatif: Jurnal IImu Pendidikan, 3(6), 3758-3768. https://doi.org/10.31004/edukatif.v3i6.1303.

Pierce, H., Jones, M. S., \& Gibbs, B. G. (2021). Early adverse childhood experiences and exclusionary discipline in high school. Social Science Research, July, 102621. https://doi.org/10.1016/j.ssresearch.2021.102621.

Sari, M., \& Irianto, A. (2020). Pengaruh Dari Pematuhan Tata Tertib Sekolah dan Keikutsertaan Siswa Dalam Ekstrakurikuler Pramuka Terhadap Disiplin Siswa Dalam Belajar Pada Siswa SMA Swasta Akreditasi A di Kota Padang. Jurnal Ecogen, 3(1), 1. https://doi.org/10.24036/jmpe.v3i1.8480.

Stark, K., \& Bettini, E. (2021). Teachers' perceptions of emotional display rules in schools: A systematic review. Teaching and Teacher Education, 104, 103388. https://doi.org/10.1016/j.tate.2021.103388.

Sugiyono. (2016). Metode Penelitian Kualitatif, Kuantitatif, dan R\&D. Alfabeta.

Syukur, A. (2015). Nilai Strategis Kompetensi Professional dan Kompetensi Pedagogik Guru 
Dalam Peningkatan Hasil Ujian Nasional (Studi Kasus di Madrasah Ibtidaiyah (MI) Global Blotongan Kota Salatiga). Inferensi, 9(2), 515. https://doi.org/10.18326/infs/3.v9i2.515536.

Tanto, O. D., Hapidin, H., \& Supena, A. (2019). Penanaman Karakter Anak Usia Dini dalam Kesenian Tradisional Tatah Sungging. Jurnal Obsesi : Jurnal Pendidikan Anak Usia Dini, 3(2), 337. https://doi.org/10.31004/obsesi.v3i2.192.

Thomas, C. L., Price, O. A., Phillippi, S., \& Wennerstrom, A. (2020). School-based health centers, academic achievement, and school discipline: A systematic review of the literature. Children and Youth Services Review, 118(September), 105467. https://doi.org/10.1016/j.childyouth.2020.105467.

Triki, N. (2021). Exemplification in research articles: Structural, semantic and metadiscursive properties across disciplines. Journal of English for Academic Purposes, 54(November 2020), 101039. https://doi.org/10.1016/j.jeap.2021.101039. 